\title{
Peran Negara Dalam Pengembangan Sistem Ekonomi Kerakyatan menurut UUD 1945
}

\author{
Zainal Arifin Hoesein \\ Fakultas Hukum Universitas Islam As-Syafi'iyah \\ Jln. Jatiwaringin Raya No. 12 Pondokgede Kota Bekasi Jawa Barat 17411 \\ arifinhoesein55@yahoo.com
}

\begin{abstract}
The concept of people economy cannot be separated with the concept of people's welfare. Both concepts, explicitly and implicitly, are contained in Article 33 of the 1945 Constitution. Referring to Article 33 of the 1945 Constitution, it is clear that the national economic system Indonesia is intended for social welfare. The problem in this research is how legal policy able to clarify the people's economic as intended in the principles of Article 33 UUD 1945? By using qualitative research method with normativejuridical approach, the study was emphasized by analyzing a variety of resources related to the issues discussed in this paper. The research concludes that the policy of people economic development becomes essential and a priority in order to realize the people prosperity. This can be achieved if the policy of people economic development is supported by the law in the form of legislation which is able to develop micro, small and medium-scale enterprises to take a part in the national business world.
\end{abstract}

Keywords: Legal Policies, People's Economic System, People Prosperity

\section{Abstrak}

Konsep ekonomi kerakyatan tidak bisa dipisahkan dengan konsep kesejahteraan rakyat. Kedua konsep secara eksplisit dan Implisit terdapat pada Pasal 33 UUD 1945. Merujuk kepada Pasal 33 UUD 1945 dimaksud terlihat jelas bahwa sistem perekonomian nasional Indonesia ditujukan untuk kesejahteraan sosial. Permasalahan dalam penelitian ini adalah bagaimanakah kebijakan hukum yang mampu menjabarkan prinsip ekonomi kerakyatan yang dikehendaki Pasal 33 UUD 1945? Dengan menggunakan metode penelitian kualitatif melalui pendekatan yuridis normatif, maka kajian ditekankan dengan menganalisis berbagai sumber yang berkaitan dengan persoalan yang dibahas dalam penulisan ini. Hasil penelitian menyimpulkan bahwa kebijakan pengembangan ekonomi kerakyatan menjadi penting dan prioritas dalam kerangka mewujudkan kesejahteraan rakyat. Hal ini dapat dicapai apabila kebijakan pengembangan ekonomi kerakyatan tersebut didukung oleh perangkat hukum berupa peraturan perundang-undangan yang mampu mengembangkan sektor usaha mikro, kecil, dan menengah agar mampu ambil peran dalam dunia usaha nasional.

Kata-kata kunci: Kebijakan hukum, sistem ekonomi kerakyatan, kesejahteraan rakyat. 


\section{Pendahuluan}

Dalam UU Nomor 17 Tahun 2007 tentang Rencana Pembangunan Jangka Panjang Nasional Tahun 2005-2025, visi pembangunan nasional 2005-2025 yang ditetapkan adalah Indonesia yang mandiri, maju, adil dan makmur. Untuk mewujudkan visi tersebut ditempuh melalui 8 misi pembangunan nasional yang satu di antaranya adalah mewujudkan masyarakat demokratis berlandaskan hukum. ${ }^{1}$

Visi "Indonesia yang mandiri, maju, adil dan makmur" merupakan gagasan besar dan komitmen penyelenggara negara dalam mewujudkan Indonesia sebagai negara yang berdaulat, kuat, mandiri, modern, berkeadilan dan berkeadaban serta berkesejahteraan. Visi ini merupakan kerangka dasar dan strategis dalam menjabarkan tujuan negara yang telah dinyatakan dalam alinea keempat Pembukaan UUD 1945"...Kemudian daripada itu untuk membentuk suatu Pemerintahan Negara Indonesia yang melindungi segenap bangsa Indonesia dan seluruh tumpah darah Indonesia dan untuk memajukan kesejahteraan umum,..". Komitmen ini, secara normatif telah dinyatakan dalam Pasal 33 UUD 1945, sehingga secara konstitusional menjadi dasar dan rujukan dalam menetapkan arah kebijakan di bidang pembangunan ekonomi yang oleh Jimly disebut sebagai konstitusi ekonomi. ${ }^{2}$

Secara historis konsep ekonomi kerakyatan merupakan gagasan di bidang ekonomi yang dikembangkan oleh Soekarno dan Hatta pada tahun 1930-an. Soekarno menggunakan istilah ekonomi rakyat yang berhadapan dengan sistem ekonomi monopoli, ${ }^{3}$ Sedangkan Mohammad Hatta menggunakan istilah

${ }^{1}$ Misi tersebut ditujukan untuk memantapkan kelembagaan demokrasi yang lebih kokoh; memperkuat peran masyarakat sipil; memperkuat kualitas desentralisasi dan otonomi daerah; menjamin pengembangan media dan kebebasan media dalam mengkomunikasikan kepentingan masyarakat dan melakukan pembenahan struktur hukum dan meningkatkan budaya hukum serta menegakkan hukum secara adil, konsekuen, tidak diskriminatif dan memihak pada rakyat kecil. Ukuran tercapainya visi Indonesia di bidang hukum adalah terwujudnya Indonesia yang demokratis, berlandaskan hukum dan keadilan, yaitu terciptanya supremasi hukum dan penegakkan hak-hak asasi manusia yang bersumber pada Pancasila dan UUD 1945 serta tertatanya sistem hukum nasional yang mencerminkan kebenaran, keadilan, akomodatif dan aspiratif. Terciptanya penegakan hukum tanpa memandang kedudukan, pangkat dan jabatan seseorang demi supremasi hukum dan terciptanya penghormatan pada hak-hak asasi manusia.

2 Jimly Asshiddiqie, Komentar Atas Undang-Undang Dasar Negara Republik Indonesia Tahun 1945, Jakarta: Sinar Grafika, 2009, hlm. 139. Dalam komentarnya Jimly menjelaskan bahwa UUD 1945 bukan saja konstitusi di bidang politik (political constitution) tetapi juga konstitusi ekonomi (economic constitution or the constitution of economic policy). Dalam konstitusi berbagai lain, ketentuan semacam ini juga biasa, termasuk di lingkungan negara-negara demokrasi yang anti komunis.

${ }^{3}$ Soekarno, Di Bawah Bendera Revolusi, Jilid Pertama, Cetakan Ketiga, Jakarta: Panitia Penerbit Di Bawah Bendera Revolusi, 1964, hlm. 31 - Pidato Soekarno pada medium Agustus 1930 saat mengajukan pembelaan di 
perekonomian ra'jat dan ekonomi ra'jat merujuk pada pemahaman tentang grass-roots economy atau ekonomi berbasis rakyat (people-based economy) dan ekonomi terpusat pada kepentingan rakyat (people-centered economy)4. Pemikiran Mohammad Hatta tersebut dijabarkan dalam beberapa tulisan yang dimuat pada harian Daulat $R a^{\prime} j a t$ : "Pengaroeh Kolonial Kapital di Indonesia" yang dimuat pada 20 Nopember 1931; "Pendirian Kita" dimuat tanggal 10 September 1932; “Krisis Dunia dan Nasib Ra'jat Indonesia" dimuat tanggal 20 September 1932; "Ekonomi Ra'jat" yang dimuat 20 November 1933; dan yang paling monumental adalah tulisannya 10 Juni 1934 yang berjudul "Ekonomi Ra'jat dalam Bahaya". Latar belakang tulisan-tulisan Mohammad Hatta pada era 1931 sampai dengan 1934 di atas didorong keprihatianan beliau dengan politik cultuurstelsel yang diterapkan Belanda, dimana kebijakan perekonomian tidak berpusat pada kepentingan rakyat dimaksud 5 .

Dalam praktik tanam paksa yang diterapkan sejak 1830, memaksa para petani untuk menanam komoditas tertentu yang ditetapkan oleh Pemerintah Hindia Belanda. Praktik ini jelas-jelas sangat menyengsarakan pribumi dan karenanya banyak kritik yang dilontarkan bahkan oleh petinggi-petinggi Belanda sendiri. Menanggapi kritikan ini, Parlemen Belanda mengundangkan Agrarisch Wet pada tahun 1870; dimana diatur bahwa monopoli Pemerintah Hindia Belanda atas hasil bumi Hindia Belanda diakhiri dengan membuka kesempatan bagi para pemilik modal Eropa untuk menanamkan investasi di daerah koloni tersebut berdasarkan hak guna usaha (erfpacht) selama 75 tahun dan hak opstal untuk selama 20 tahun 6. Dampak Agrarisch Wet terhadap pribumi ternyata tidak lebih baik, menurut istilah Ismawan, hanya berganti operator saja; yang semula eksploitasi dilakukan oleh Pemerintah Hindia Belanda di zaman culturstelsel berpindah tangan kepada para pihak swasta (particulier initiatief). Dengan kesempatan ini, maka berdirilah

\footnotetext{
Landraad Bandung, menyinggung bahwa ekonomi rakyat telah terdesak bahkan terpadamkan oleh sistem ekonomi monopoli yang disempitkan.

4 Sri Edi Swasono, Kebangsaan, Kerakyatan, dan Kebudayaan dalam "Prosiding Kongres Pancasila VI: Penguatan, Sinkronisasi, Harmonisasi, Integrasi Pelembagaan dan Pembudayaan Pancasila dalam Rangka Memperkokoh Kedaulatan Bangsa”, Ambon, 31 Mei - 01 Juni 2014, hlm. 89.

${ }^{5}$ Ibid.

${ }^{6}$ Bambang Ismawan, Memberdayakan Perekonomian Rakyat dalam Transformasi Kesejabteraan: Pemenuban Hak. Ekonomi dan Kesehatan Semesta, LP3ES, Jakarta, 2016, hlm.1-4.
} 
perkebunan-perkebunan besar (onderneming) yang dimiliki oleh swasta, yang sebagian diambil alih melalui nasionalisasi yang menjadi perkebunan negara sekarang ini. Karena adanya investasi swasta berdasarkan prinsip business as usual, maka para pemodal Eropa melalukan inovasi dengan bantuan dukungan infrastruktur ekonomi dari De Javasche Bank menerapkan teknologi modern dan jaringan internasional. Akibatnya, perkebunan (baca perekonomian) pribumi walaupun dipersilahkan bersaing secara terbuka, namun tetap kalah dan semakin terpuruk dari perkebunan swasta Eropa tersebut, karena pada umumnya perkebunan dan pertanian pribumi berskala kecil, berteknologi sederhana, dan berdimensi lokal. Kesengsaraan para petani inilah yang mendorong munculnya pemikiran amanat penderitaan rakyat (Ampera) yang diusung oleh para pejuang kemerdekaan.7 Oleh karena itu, tatkala Mohammad Hatta menyusun konsep ekonomi rakyat tidak boleh ditafsirkan lepas dari penderitaan dan kesengsaraan rakyat, yaitu harus mampu melakukan pemberdayaan ekonomi untuk kesejahteraan rakyat. Dengan demikian, konsep ekonomi kerakyatan tidak bisa dipisahkan dengan konsep kesejahteraan rakyat. Kedua konsep secara eksplisit dan implisit terdapat pada Pasal 33 UUD 1945.

Merujuk kepada latar belakang perumusan Pasal 33 UUD 1945 tersebut, terdapat dua hal penting yang selalu menjadi perdebatan ketika menempatkan posisi negara dalam penetapan kebijakan ekonomi, yaitu konsep hak menuasasi/konsep penguasaan publik dan konsep kepemilikan perdata dari negara terhadap sumber daya ekonomi/sumber daya alam beserta konsekuensi hubungan hukumnya. Hal ini dapat ditelusuri terhadap beberapa kebijakan di bidang ekonomi pada masa Pemerintahan Soekarno dan masa pemerintahan Soeharto/Orde Baru dan masa pemerintahan orde reformasi. ${ }^{8}$

${ }^{7}$ Ibid, hlm.2.

8 Pada masa Pemerintahan Soekarno, penjabaran Pasal 33 UUD 1945 dituangkan dalam Undang-Undang Nomor 5 Tashun 1960 tentang Ketentuan Pokok-Pokok Agraria. Sedangkan dalam masa Pemerintahan Soeharto dituangkan dalam berbagai peraturan perundang-undangan seperti UU No. 1 Tahun 1976 tentang Penanaman Modal Asing; UU No. 5 Tahun 1967 tentang Ketentuan Pokok Kehutanan; UU No. 11 Tahun 1967 tentang Ketentruan Pokok Pertambangan. Produk hukum tersebut merupakan arah politik hukum di bidang ekonomi pada masa pemerintahan masing-masing. Pada masa Soekarno posisi negara dalam konsep hak menguasai sangat kuat dan berpihak pada kesejahteraan rakyat yang oleh Moh. Mahfud MD disebut sebagai produk hukum yang populis (lihat Moh. Mahfud MD, Perkembangan Politik. Hukum, Studi tentang Pengarub Konfigurasi Politik terbadap Produk. Hukum di Indonesia, disertasi Doktor dalam Ilmu Hukum di Univeristas Gajah Mada [Yogyakarta: UGM, 1993, hlm. 6061]).Sedangkan produk hukum di bidang ekonomi masa pemerintahan Soeharto lebih condong pada kepentingan 
Demikian pula dalam putusan Mahkamah Konstitusi dalam beberapa perkara terkait dengan konsep penguasaan negara terhadap sumber daya alam sebagai sumber daya ekonomi untuk kesejahteraan rakyat menyatakan bahwa, "Konsepsi penguasaan oleh Negara merupakan konsepsi hokum public yang berkaitan dengan prinsip kedaulatan rakyat yang dianut dalam UUD 1945, baik di bidang politik (demokrasi politik) maupun enonomi (demokrasi ekonomi). Dalam paham kedaulatan rakyat itu, rakyatlah yang diakui sebagai sumber, pemilik dan sekaligus pemegang kekuasaan tertinggi dalam kehidupan bernegara, sesuai dengan doktrin dari rakyat, oleh rakayat dan untuk rakyat. Dalam pengertian kekuasaan tertinggi tersebut, tercakup pula pengertian kepemilikan public oleh rakyat secara kolektif."9

Beberapa kebijakan di bidang ekonomi sebagaimana diuraikan di atas, telah terjadi perbedaan tafsir dan penerapan Pasal 33 UUD 1945 tentang penguatan peran negara dalam menetapkan arah kebijakan atau politik hukum di bidang ekonomi. Dalam perspektif prinsip ekonomi kerakyatan sebagaimana yang diamanatkan oleh para perumus Pasal 33 UUD 1945, maka beberapa kebijakan atau politik hukum di bidang ekonomi pada masa orde baru dan orde reformasi dapat dinilai telah menjauh dari prinsip yang dianut oleh Pasal 33 UUD 1945. Apabila segala kebijakan di bidang ekonomi tidak sejalan dengan UUD 1945 sebagai hukum tertinggi, maka kebijakan ekonomi yang diambil dan ditetapkan dianggap bertentangan dengan UUD 1945.

Walaupun rumusan konstitusi yang menyangkut tata ekonomi yang seharusnya dibangun, belum cukup jelas sehingga tidak mudah untuk dijabarkan bahkan dapat diinterpretasikan bermacam-macam, tergantung siapa keyakinan

pemilik modal terutama pada sektor kehutanan dan pertambangan. Demikian pula pada masa orde reformasi kebijakan di bidang ekonomi lebih berpihak pada kepentingan pemilik modal dan sifatnya lebih masif. Pada masa ini diperkenalkan program privatisasi sektor publik yang semestinya merupakan tanggungjawab langsungnegara. Privatisasi dipahami sebagai tindakan atau proses untuk memindahkan urusan perdagangan atau industri dari kepemilikian atau kontrol pemerintah menjadi kontrol tau milik perusaan pribadi/swasta. Dalam kurun waktu 1999-2008 telah diterbitkan sekitar 8 (delapan) undang-undang yang terkait dengan sumber daya alam dan kelautan.

9 Putusan Mahkamah Konstitusi Perkara Nomor 001-021-022/PUU-I/2003 tentang Pengujian UU No. 20 Tahun 2002 tentang Ketenagalistrikan (hal.333); Lihat pula Putusan Perkara Nomor 002/PUU-I/2003 mengenai Pengujian UU No. 22 Tahun 2001 Tentang Minyak dan Gas Bumi (hal.207), Putusan Perkara No. 058-059-060063/PUU-II/2004 mengenai Pengujian UU No. 7 Tahun 2004 tentang Sumber daya Air (hal.498-499 dan 514515), dan Putusan No. 21-22/PUU-V/2007 mengenai Pengujian UU No.25 Tahun 2007 tentang Penanaman Modal (hlm.271). 
ideologi pengusanya, tetapi dari analisis historis sebenarnya makna atau ruhnya cukup jelas $^{10}$. Ruh tata ekonomi usaha bersama yang berasas kekeluargaan adalah tata ekonomi yang memberikan kesempatan kepada seluruh rakyat untuk berpartisiasi sebagai pelaku ekonomi. Tata ekonomi yang seharusnya dibangun adalah bukan tata ekonomi yang monopoli atau monopsoni atau oligopoli. Tata ekonomi yang dituntut konstitusi adalah tata ekonomi yang memberi peluang kepada seluruh rakyat atau warga negara untuk memiliki aset dalam ekonomi nasional. Tata ekonomi nasional adalah tata ekonomi yang membedakan secara tegas barang dan jasa mana yang harus diproduksi oleh pemerintah dan barang dan jasa mana yang harus diproduksi oleh sektor privat atau sektor non pemerintah. Mengenai bentuk kelembagaan ekonomi, walaupun dalam penjelasan Pasal 33 UUD 1945 dinterpretasikan sebagai bentuk koperasi, tetapi tentu harus menyesuaikan dengan perkembangan masyarakat dan lingkungan.

Memang saat ini cukup banyak peraturan perundang-undangan yang sudah dibentuk dan dijalankan dalam rangka melaksanakan amanat Pasal 33 UUD 1945.11 Peraturan perundang-undangan yang sudah diterbitkan tersebut perlu dikaji ulang apakah telah sejalan dengan karakteristik sistem ekonomi kerakyatan sebagaimana yang terkandung dalam Pasal 33 UUD 1945? Karena kebijakan ekonomi yang berpihak pada pemilik modal pengaturan dalam undang-undang cukup kuat dan hampir di semua sektor sumber daya alam, sedangkan kebijakan yang terkait dengan ekonomi kerakyatan seperti perkoperasian dan usaha mikro, kecil dan menengah (UMKM) sangat lemah. Oleh karena itu, pengembangan

10Pasal 27 UUD 1945: bahwa setiap warga negara berhak untuk mendapatkan pekerjaan dan penghidupan yang layak, sedangkan Pasal 33 1945: bahwa ekonomi nasional disusun dalam bentuk usaha bersama yang berasaskan kekeluargaan.

11 Peraturan Perundang-undangan di bidang ekonomi yang diterbitkan pada masa orde reformasi antara lain Undang-Undang Nomor 41 Tahun 1999 Tentang Kehutanan; Undang-Undang Nomor 29 Tahun 2000 Tentang Perlindungan Varietas Tanaman; Undang-Undang Nomor 22 Tahun 2001 Tentang Minyak dan Gas Bumi; Undang-Undang Nomor 20 Tahun 2002 Tentang Ketenagalistrikan; Undang-Undang Nomor 27 Tahun 2003 Tentang Panas Bumi; Undang-Undang Nomor 7 Tahun 2004 entang Sumber daya Air; Undang-Undang Nomor 18 Tahun 2004 Tentang Perkebunan; Undang-Undang Nomor 19 Tahun 2004 Perubahan UU Kethutanan; Undang-Undang 31 Tahun 2004 Tentang Perikanan; Undang-Undang Nomor 25 Tahun 2007 Tentang Pasar Modal; Undang-Undang Nomor 27 Tahun 2007 Tentang Pengelolaan Wilayah Pesisir dan Pulau Kecil; Undang-Undang Nomor 30 Tahun 2007 Tentang Energi; Undang-Undang Nomor 40 Tahun 2007 tentang Perseroan Terbatas, Undang-Undang Nomor 4 Tahun 2009 tentang Pertambangan Mineral dan Batubara, Undang-Undang Nomor 39 Tahun 2014 tentang Perubahan UU Perkebunan, dan lain sebagainya. Sedangkan Undang-Undang yang diterbitkan di bidang ekonomi kerakyatan adalah Undang-Undang Nomor 25 Tahun 1992 tentang Perkoperasian, Undang-Undang Nomor 20 Tahun 2008 tentang Usaha Mikro, Kecil dan Menengah. 
kebijakan ekonomi kerakyatan perlu ditelusuri dan dikaji ulang mengenai kebijakan terhadap pengembangan usaha mikro, kecil dan menengah. Hal ini didasarkan pada banyaknya peraturan perundang-undangan dalam menetapkan dasar yuridisnya "mengingat" menggunakan Pasal 33 UUD 1945, namun materi muatan peraturan perundang-undangan tersebut tidak mencerminkan nilai yang terkandung dalam Pasal 33 UUD 1945. Hal ini berarti Pasal 33 UUD 1945 sebagai rujukan beberapa peraturan perundang-undangan yang terkait dengan perekonomian hanya bersifat formalistis atau proforma. ${ }^{12}$

Kajian tentang sistem ekonomi kerakyatan dalam perspektif UUD 1945 sangat relevan dilakukan, mengingat saat ini muncul berbagai kebijakan ekonomi yang ditetapkan justru semakin menjauh dari semangat Pasal 33 UUD 1945.

\section{Rumusan Masalah}

Sejalan dengan pokok pikiran sebagaimana diuraikan dalam latar belakang di atas, maka rumusan masalah dalam penelitian ini (research question), bagaimanakah peran negara dalam menetapkan arah kebijakan hukum atau politik hukum yang mampu menjabarkan prinsip ekonomi kerakyatan yang dikehendaki Pasal 33 UUD 1945 ?

\section{Tujuan Penelitian}

Penelitian ini bertujuan untuk mengetahui dan menemukan penguatan peran negara dalam menetapkan arah kebijakan hukum atau politik hukum yang mampu menjabarkan prinsip ekonomi kerakyatan yang dikehendaki Pasal 33 UUD 1945.

\section{Metode Penelitian}

Penelitian ini merupakan kajian ilmu hukum dengan pendekatan yuridis normatif. Dalam pendekatan ini dilakukan telaah terhadap data sekunder berupa dokumen atau literatur, yang dilakukan dengan cara mengumpulkan informasi yang diperoleh melalui peraturan perundang-undangan, data-data tertulis, buku-buku, hasil seminar, hasil penelitian, pengkajian dan tulisan atau referensi lain, serta

12 Jimly Asshiddiqie, Konstitusi Ekonomi, Kompas Media Nusantara, Jakarta, 2010, hlm. viii. 
penelusuran data dan informasi melalui website yang berkaitan dengan persoalan yang dibahas dalam penulisan ini.

Data sekunder yang dikumpulkan untuk diolah dan dianalisis tersebut terdiri atas: a. sumber-sumber hukum primer berupa peraturan perundang-undangan dan dokumen-dokumen hukum; b. sumber hukum sekunder berupa buku-buku, hasil penelitian, makalah, hasil kajian, dan artikel hasil pemikiran para ahli hukum; c. sumber hukum tersier berupa kamus hukum, encyclopedia, serta informasiinformasi lain menyangkut masalah ekonomi kerakyatan.Data sekunder yang sudah diperoleh kemudian dianalisis secara kualitatif dan dipaparkan untuk keperluan penarikan kesimpulan. Adapun teknik penarikan kesimpulan yang digunakan adalah teknik deduktif, dimana penemuan suatu hal/kasus digunakan untuk keperluan generalisasi masalah.

\section{Hasil Penelitian dan Pembahasan}

\section{Kerangka Dasar Ekonomi Kerakyatan Berdasarkan Pasal 33 UUD 1945}

Pasal 33 UUD 1945 berada di bawah Bab XIV dengan perubahan judul pada perubahan keempat menjadi 'Perekonomian Nasional dan Kesejahteraan Sosial'. Merujuk kepada judul dimaksud terlihat jelas bahwa sistem perekonomian nasional Indonesia ditujukan untuk kesejahteraan sosial. Hal ini senada dengan pendapat Dawam Rahardjo yang membahas Pasal 33 dari perspektif ekonomi. Menurut Dawam Rahardjo, ${ }^{13}$ jika dilihat dengan seksama, maka Pasal 33 bertujuan untuk mecapai kesejahteraan sosial. Dalam konsteks kesejahteraan, UUD 1945 menggunakan dua istilah, yaitu kesejahteraan umum dan kesejahteraan sosial. Istilah kesejahteraan umum dapat ditemui dalam Alinea IV Pembukaan (Preambule) UUD 1945; sedangkan istilah kesejahteraan sosial terdapat pada judul Bab XIV tersebut di atas. Tidak ada penjelasan lebih lanjut mengenai kedua istilah dimaksud. Menurut Dawam Rahardjo istilah kesejahteraan sosial lebih sering digunakan dalam konteks wacana pembangunan. Hal ini ditafsirkannya berdasarkan penggunaan istilah tersebut pertama kalinya oleh Bung Karno dala

13 M. Dawam Rahardjo, Ekonomi Politik Pembangunan, LSAF, Jakarta, 2012, hlm. Xxvii. Lihat pula Dawam. Rahardjo dalam, Ekonomi Pancasila Dalam Tinjauan Filsafat Ilmu. http:// www. ekonomikerakyatan.ugm.ac.id., diakses tanggal 6 Januari 2004. 
pidatonya di depan Badan Penyelidik Usaha Persiapan Kemerdekaan Indonesia (BPUPKI) dalam menjelaskan rumusan dasar negara yang diajukannya. Bung Hatta menyetujui penggunaan istilah tersebut, namun beliau menggunakan istilah keadilan sosial daripada kesejahteraan sosial. Istilah keadilan sosial lebih menekankan pada distribusi kesejahteraan yang diperoleh dalam pembangunan yang lebih adil dan merata. ${ }^{14}$

Makna kesejahteraan sosial sebagaimana tercantum dalam Bab XIV UUD 1945 tersebut di atas, menurut Sri Edi Swasono ${ }^{15}$ merupakan rumusan sistem ekonomi Indonesia yang disebutnya sebagai Doktrin Kesejahteraan Indonesia. Kesehateraan sosial bersama-sama dengan kesejahteraan umum termasuk dalam kesejahteraan publi (public welfare) yang merupakan tanggungjawab dan misi negara mewujudkannya. Oleh karena itu, tugas utama negara adalah memasukan kesejahteraan rakyat Indonesia seluruhnya di samping 'melindungi segenap tumpah darah', 'mencerdaskan kehidupan bangsa', 'turut serta dalam menegakkan perdamaian dunia yang abadi' sebagaimana termaktub dalam Aline IV UUD 1945. Istilah kesejahteraan umum merupakan lawan dari kesejahteraan individu. Oleh karena itu, ukuran kesejahteraan bukan berbasis pendapatan individu; melainkan komunal. Dalam perspektif filsafat (hukum), ukuran kesejahteraan umum digambarkan oleh teori Jeremy Bentham ${ }^{16}$ 'the greatest happiness for the greatest number', artinya jika sebagian anggota masyarakat merasakan manfaat dan merasa senang dengan kebijakan atau situasi tertentu, maka itulah kesejahteraan umum. Namun sebaliknya, jika "the greatest happiness for the smallest number" maka kesejahteraan umum belum terwujud, sehingga negara memiliki tanggungjawab untuk mengubahnya menjadi kesejahteraan bersama. Secara kuantitatf, makna kesejahteraan sosial menurut Rizal Ramli17 dapat diukur dari (1) Status gizi; (2) status kesehatan yang terlihat dari angka harapan hidup; (3) status pendidikan, pekerjaan

\footnotetext{
${ }^{14}$ Ibid., hlm. xxxii.

15 Abdul Madjid dan Sri Edi Swasono (eds.), Wawasan Ekonomi Pancasila, UI Press, Jakarta, 1981, hlm. 9.

${ }^{16} J$ Jeremy Bentham, The Theory of Legislation, NM. Tripathi Private Limited, Bombay, 1979, hlm. 23-25

17 Rizal Ramli,Telaah Wacana Ekonomi Kerakyatan dalam Ekonomi Kerakyatan, Lembaga Suluh Nusantara Bekerjasama dengan American Institute For Indonesian Studies (AIFIS), 2014, hlm. 11.
} 
yang mencukupi kebutuhan hidup, dan; (4) prevalensi kejadian penyakit dan lainlain, yang harus diukur secara kuantitatif. Sejalan dengan pikiran utilitarianisme di atas, maka ukuran kesejahteraan rakyat yang paling penting adalah tercukupinya kebutuhan dasar atau pokok hidup, bukan pertumbuhan ekonomi atau nilai tukar.

Sesungguhnya Pasal 33 UUD 1945 merupakan dasar demokrasi ekonomi Indonesia yang mengacu pada pemikiran Hatta tentang ekonomi kerakyatan, karena istilah ekonomi kerakyatan memang tidak ditemukan secara eksplisit dalam UUD 1945. ${ }^{18}$ Namun demikian, secara esensial, makna demokrasi ekonomi dimaksud mengacu pada definisi kata 'kerakyatan' sebagaimana dikemukakan oleh Hatta dalam tulisannya pada harian Daulat $R a^{\prime} j a t .{ }^{19}$ Selain itu penggunaan kata kerakyatan pada Sila keempat Pancasila pun dapat ditafsirkan bahwa demokrasi ekonomi adalah ekonomi kerakyatan. Selanjutnya dalam menjelaskan Pasal 33, Hatta menerangkan sebagai berikut:20

1. Makna asas kekeluargaan yang terdapat dalam Pasal 33 ayat (1) UUD 1945:

Azas kekeluargaan itu ialah koperasi. Azas kekeluargaan itu adalah istilah dari Taman Siswa untuk menunjukkan bagaimana guru dan murid-murid yang tinggap padanya hidup sebagai suatu keluarga. Itu pulalah hendaknya corak koperasi Indonesia.

2. Makna dikuasai oleh negara Pasal 33 ayat (2) UUD 1945.

Pengertian dikuasai oleh negara haruslah diartikan mencakup makna penguasaan oleh negara dalam arti luas yang bersumber dan diturunkan dari konsepsi kedaulatan rakyat Indonesia atas segala sumber kekayaan "bumi, air dan kekayaan alam yang terkandung di dalamnya", termasuk pula di dalamnya pengertian kepemilikan publik oleh kolektivitas rakyat atas sumber-sumber kekayaan dimaksud. Rakyat secara kolektif itu dikonstruksikan oleh UUD 1945 memberikan mandat kepada negara untuk mengadakan kebijakan (beleid) dan tindakan pengurusan (bestuursdaad), pengaturan (regelendaad), pengelolaan (beheersdaad), dan pengawasan (toezichthoudensdaad) untuk tujuan sebesarbesarnya kemakmuran rakyat ${ }^{21}$.

3. Makna digunakan untuk sebesar-besarnya kemakmuran rakyat yang terdapat dalam Pasal 33 ayat (3).

\footnotetext{
${ }^{18}$ Revrisond Baswir (1995), Tiada Ekonomi Kerakyatan Tanpa KedaulatanRakyat, dalam Baswir (1997), Agenda Ekonomi Kerakyatan, Pustaka Pelajar, Yogyakarta (2000), hlm. 5.

${ }^{19}$ Ibid

${ }^{20}$ Moh. Hatta, Beberapa Pasal Ekonomi, Jakarta: Perpustakaan Perguruan Kementerian P dan K, 1954, hlm. 5. Lihat juga Moh. Hatta, Demokrasi Kita, tulisan yang dimuat dalam majalah Panji Masyarakat No. 22/ThII/1960, Bandingkan Moh. Hatta, Islam dan Sosialisme, artikel yang dimuat Majalah Panji Masyarakat No. 20 Th. II, 28 Maret 1960.

21 Putusan Mahkamah Konstitusi Nomor 002/PUU-I/2003 sebagaimana dimua dalam Berita Negara Republik Indonesia Nomor 01 Tahun 2005, tanggal 04 Januari 2005, hlm. 208-209.
} 
4. Makna Demokrasi Ekonomi yang terdapat dalam Pasal 33 ayat (4):

Demokrasi ekonomi, menurut Hatta (1932), ${ }^{22}$ sebagaimana halnya demokrasi Indonesia, bersumber pada nilai demokrasi asli di desa-desa di Indonesia. Ada tiga unsur demokrasi di Indonesia: (1) musyawarah, (2) kemerdekaan berpendapat, dan (3) tolong menolong. Dengan menerapkan pilar demokrasi ekonomi ini, tidak ada lagi sebagian kecil orang ataupun golongan yang menguasai kehidupan orang banyak hanya karena ia menguasai faktor produksi seperti sekarang ini. Idealnya keperluan dan kemauan rakyat banyak yang harus menjadi pedoman perusahaan dan penghasilan, Karenanya, semua cabang produksi yang memberikan penghasilan besar dan mengenai hajat hidup orang banyak harus dikelola secara bersama di bawah penjagaan rakyat dengan perantaraan badan-badan perwakilannya.

Perlu juga dicermati bahwa negara juga memiliki kekuasaan atas cabang-cabang produksi yang penting bagi negara dan/atau menguasai hajat hidup orang banyak, sebagaimana ditetapkan dalam Pasal 33 ayat (2) UUD 1945. Cabang produksi yang menguasai hajat hidup orang banyak adalah cabang produksi yang termasuk dalam kategori public utility. Menurut Maruarar Siahaan dan Harjono,23 penafsiran penguasaan negara ini tidak dapat diartikan dalam konsepsi kepemilikan perdata, melainkan harus dikaitkan dengan kedudukan negara sebagai entity yang berdaulat, yang oleh karenanya, kewenangannya meliputi pengaturan hal-hal yang berada di wilayah kedaulatannya, meskipun diluar kepemilikannya, termasuk di dalamnya untuk menarik pemilikan orang lain untuk dikuasai negara.

Berdasarkan penjelasan di atas, maka dapat terjadi bahwa (i) cabang produksi yang penting bagi negara dan menguasai hidup orang banyak, (ii) penting bagi negara tetapi tidak menguasai hajat hidup orang banyak, dan (iii) tidak penting bagi negara tetapi menguasai hajat hidup orang banyak. Ketiga kondisi ini menjadi penguasaan negara dan harus dipergunakan untuk sebesar-besarnya kemakmuran rakyat, seperti digambarkan dalam tabel berikut ${ }^{24}$ :

\footnotetext{
22 Hatta, Op.Cit., hlm. 5.

23 Pendapat Maruarar Siahaan dan Harjono termuat dalam Putusan Mahkamah Konstitusi Nomor 002/PUU-I/200, Op.Cit. hlm. 208-209.

${ }^{24}$ Efridani Lubis, Perlindungan dan Pemanfaatan Sumber Daya Genetik Berdasarkan Penerapan Konsep Sovereign Right dan Hak Kekayaan Intelektual, Penerbit Alumni, Bandung, 2009, hlm. 127.
} 
Tabel 1.

Penguasaan Negara atas SDA dan Cabang Produksi yang Menguasai Hajat Hidup Orang Banyak

\begin{tabular}{|c|c|c|c|}
\hline No & SDA/Cabang Produksi & Hajat Hidup Masyarakat & $\begin{array}{c}\text { Kekuasaan } \\
\text { Negara }\end{array}$ \\
\hline 1 & Bumi & Tidak mensyaratkan & Dikuasai Negara \\
\hline 2 & Air & Tidak mensyaratkan & Dikuasai Negara \\
\hline 3 & $\begin{array}{l}\text { Kekayaan alam dalam } \\
\text { bumi/air }\end{array}$ & Tidak mensyaratkan & Dikuasai Negara \\
\hline 4 & $\begin{array}{l}\text { Penting/strategis bagi } \\
\text { negara }\end{array}$ & $\begin{array}{l}\text { Menguasai hajat hidup } \\
\text { orang banyak }\end{array}$ & Dikuasai Negara \\
\hline 5 & Penting Bagi Negara & $\begin{array}{l}\text { Tidak menguasai hajat } \\
\text { hidup orang banyak }\end{array}$ & Dikuasai Negara \\
\hline 6 & $\begin{array}{l}\text { Tidak penting } \\
\text { Negara }\end{array}$ & $\begin{array}{l}\text { Menguasai hajat hidup } \\
\text { orang banyak }\end{array}$ & Dikuasai Negara \\
\hline 7 & $\begin{array}{l}\text { Tidak penting } \\
\text { Negara }\end{array}$ & $\begin{array}{l}\text { Tidak menguasai hajat } \\
\text { hidup orang banyak }\end{array}$ & $\begin{array}{l}\text { Tidak dikuasai } \\
\text { Negara }\end{array}$ \\
\hline
\end{tabular}

Sumber: Lubis, 2010:127

Dari Tabel 1 di atas, terlihat bahwa peran negara dalam mengelola sumber daya alam Indonesia (SDA) sangat besar sekali untuk sebesar-besar kemakmuran rakyat. Peran negara tersebut bertujuan untuk menghindari terjadinya kepincangan penguasaan sumber daya pembangunan akibat penguasaan oleh pihak swasta. Dengan penguasaan oleh negara maka hajat hidup orang banyak yang dalam teori ekonomi disebut sebagai kebutuhan dasar manusia (human basic needs) - dapat diproduksi dan didistribusikan secara lebih merata untuk setiap warga negara. Sejalan dengan pemikiran ini, maka Demokrasi Ekonomi sebagai landasan ekonomi kerakyatan yang terkandung dalam Pasal 33 UUD 1945 di atas tidak bisa dilepaskan dari peran negara dalam memajukan sektor ekonomi kerakyatan untuk tujuan pendistribusian kesejahteraan rakyat yang merata.

\section{Peran Negara dalam Sistem Ekonomi Kerakyatan}

Sebagaimana telah dijelaskan di atas, penerapan Pasal 33 tidak bisa dilepaskan dari peran negara. Negara sebagai pengelola sumber daya alam Indonesia mengembangkan dan menggunakannya untuk sebesar-besar kemakmuran rakyat dengan menggunakan prinsip ekonomi kerakyatan. Oleh karena itu, jika dipahami 
secara keseluruhan Pasal 33 UUD 1945 maka hubungan antara sistem ekonomi kerakyatan, sumber daya alam dan cabang-cabang produksi penting serta negara utuk kesejahteraan masyarakat tergambar sebagai berikut:

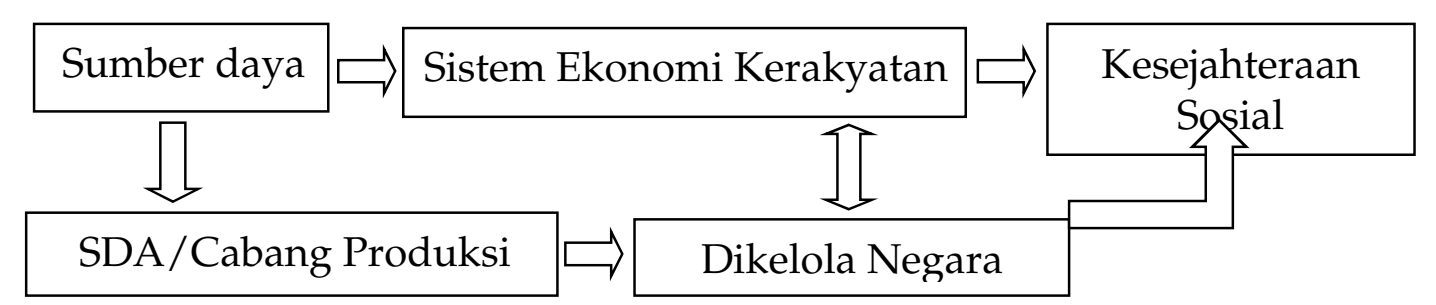

Berdasarkan penjelasan di atas, terlihat bahwa negara berkewajiban untuk mengelola sumber daya alam (SDA) dan cabang-cabang produksi penting menggunakan sistem ekonomi kerakyatan untuk kesejahteraan seluruh rakyat Indonesia. Penggunaan SDA dalam kegiatan ekonomi bukanlah hal baru; justru cikal bakal dan penyokong perekonomian Indonesia adalah SDA ${ }^{25}$. Saat ini lebih dari 50\% rakyat Indonesia hidup dipedesaan, yang kehidupannya tergantung kepada hasil alam, dan diantara mereka bahkan masuk kategori miskin yang menurut statistik awal 2012 mencapai 15,72\%. Oleh karena itu, konsekuensinya adalah bahwa setiap strategi pembangunan yang mengarah pada peningkatan kesejahteraan masyarakat harus difokuskan pada pembangunan daerah pendesaan. Mengutamakan pembangunan di desa tidak berarti seluruh dana dan daya dipusatkan dan diarahkan kepada pembangunan desa, dengan menelantarkan daerah kota. Pembangunan pedesaan justru memerlukan dukungan dan bantuan pembangunan yang lebih pesat dan lebih maju, khususnya dalam rangka industrialisasi. Pada saat industrialisasi menjadi pilihan, maka penggunaan teknologi menjadi pilihan strategis. Peran teknologi dalam pembangunan pedesaan penting artinya dalam penciptaan struktur dan keadaan ekonomi yang lebih baik. ${ }^{26}$

${ }^{25}$ VOC sebagai agen yang memperkenalkan sistem ekonomi modern di Hindia Belanda dulu memperdagangkan rempah-rempah yang merupkah hasil alam Indonesia. Hal ini kemudian berkembang menjadi perusahaan-perusahaan perkebunan, yang sebagian masih bertahan sampai hari ini berdasarkan naionalisasi dan dikelola oleh PTPN yang merupakan BUMN.

${ }^{26}$ Amiruddin Idris, Penguatan Ekonomi Kerakyatan Berdasarkan Demokrasi Ekonomi, Makalah di sampaikan dalam Diskusi Ilmiah MPR RI dan Universitas Almuslim, 2012, hlm. 5 
Dalam konteks arti membangun, cakupannya cukup luas meliputi pembangunan fisik dan non fisik. Dalam artian non fisik selain peningkatan skill atau kemampuan, ini juga meliputi pembangunan cara berpikir dan kesadaran untuk bebas dari keterbelakangan, atau berkeinginan kuat untuk hidup dengan cara yang lebih baik dan bertanggungjawab. Oleh karena itu, dalam strategi maupun program pelaksanaannya, ekonomi kerakyatan mengandung tiga unsur pokok, yaitu demokrasi, keadilan sosial dan bersifat populistik, dan implementasinya menjadi tugas negara untuk merumuskan sistem perekonomian yang memenuhi tiga unsur tersebut dan tentu saja menerapkannya pada gilirannya. ${ }^{27}$

Tujuan jangka pendek kebijakan itu adalah untuk menghapuskan penggolonggolongan status sosial-ekonomi masyarakat, baik berdasarkan ras maupun berdasarkan tingkat penguasaan faktor-faktor produksi. Sedangkan tujuan jangka panjangnya adalah untuk mengoreksi struktur ekonomi kolonial yang diwariskan oleh pemerintah Hindia Belanda, serta untuk meningkatkan kemampuan masyarakat dalam mengendalikan jalannya roda perekonomian Indonesia. Penerapan sistem ekonomi kerayaktan ini memang pasang surut; sehingga belum bisa dijadikan barometer keberhasilan sistem ekonomi di Indonesia.

Namun demikian, prinsip ekonomi kerakyatan sebagaimana dicantumkan dalam Pasal 33 UUD 1945 belum pernah dijadikan pedoman dalam menjalankan perekonomian di Indonesia. Setelah Indonesia merdeka, sekalipun praktek ekonomi kolonial Belanda menjadi dasar utama pengembangan sistem ekonomi kerakyatan dimaksud, namun pada kenyataannya sistem ini belum diterapkan secara penuh pada awal kemerdekaan. Sebagaimana diketahui, sistem perekonomian di dunia dapat dibagi dua besar: ekonomi liberal/kapitalis, dan ekonomi tertutup/sosialisme. Menurut Partadiredja, ${ }^{28}$ bahwa sebagian besar negara-negara sedang berkembang, termasuk Indonesia, menganut sistem ekonomi campuran, karena terdapat pemilikan swasta perseorangan atas alat-alatproduksi yang berdampingan dengan pemilikan negara, dan bahkan pemilikan kelompok-kelompok persekutuan adat. Mekanisme harga dan pasar bebas, hidupberdampingan dengan

\footnotetext{
${ }^{27}$ Ibid.

${ }^{28}$ Ace Partadiredja, Pengantar Ekonomika, BPFE UII, Yogyakarta, 1984, hlm. 78
} 
perencanaan yang dilakukan oleh pemerintah. Sebagian besar hargabarang dan jasa dan faktor produksi ditentukan oleh kekuatan permintaan dan penawaran.Pemerintah juga mempengaruhi kekuatan permintaan dan penawaran tersebut melaluikebijaksanaan harga, termasuk penetapan upah minimum.

Melihat perkembangan di Indonesia, maka sistem perekonomian di Indonesia setelah kemerdekaan dapat disarikan sebagai berikut:

Tabel 2.

Penerapan Sistem Ekonomi Indonesia Pasca Kemerdekaan

\begin{tabular}{|c|c|c|}
\hline Tahun & $\begin{array}{c}\text { Sistem } \\
\text { Ekonomi }\end{array}$ & Indikator \\
\hline $\begin{array}{l}1945-1950 \\
\text { (Orla) }\end{array}$ & $\begin{array}{l}\text { Pemulihan } \\
\text { inflasi } \\
\text { yang } \\
\text { sangat } \\
\text { tinggi }\end{array}$ & $\begin{array}{l}\checkmark \text { Berlakunya lebih dari satu mata uang (mata } \\
\text { uang De Javasche Bank, mata uang pemerintah } \\
\text { Hindia Belanda, dan mata uang pendudukan } \\
\text { Jepang, dan ORI) } \\
\checkmark \text { Menanggulangi masalah-masalah ekonomi yang } \\
\text { mendesak, yaitu: masalah produksi dan } \\
\text { distribusi makanan, masalah sandang, serta } \\
\text { status dan administrasi perkebunan-perkebunan } \\
\checkmark \text { Swsembada pangan (Kasimo Plan) }\end{array}$ \\
\hline $\begin{array}{l}1950-1957 \\
\text { (Orla) }\end{array}$ & $\begin{array}{l}\text { Ekonomi } \\
\text { Liberal }\end{array}$ & $\begin{array}{l}\checkmark \text { Pemotongan nilai uang (gunting Syarifuddin) } \\
\checkmark \text { Menumbuhkan wiraswastawan pribumi } \\
\quad \text { (Program Banteng) } \\
\checkmark \text { Pengambilalihan perusahaan-perusahaan } \\
\text { Belanda (Program Nasionalisasi) }\end{array}$ \\
\hline 1959-1967 & Ekonomi & $\checkmark$ Pembentukan Deklarasi Ekonomi (Dekon) \\
\hline (Orla) & Etatisme & $\begin{array}{l}\checkmark \text { Devaluasi } 2 \text { kali (25 Agustus } 1959 \text { dan } 13 \\
\text { Desember 1965) untuk menekan inflasi }\end{array}$ \\
\hline $1967-1998$ & Ekonomi & $\checkmark$ Investasi asing yang sangat terbuka \\
\hline (Orba) & Neoliberal & $\begin{array}{l}\checkmark \text { Pemberian peran yang besar pada sektor } \\
\text { moneter } \\
\checkmark \text { Privatisasi/swastanisasi } \\
\checkmark \text { menyerahkan layanan publik pada mekanisme } \\
\text { pasar seperti pendidikan, kesehatan, air } \\
\text { minum/bersih }\end{array}$ \\
\hline $1998-1999$ & Pemulihan & $\checkmark$ Menaikkan tingkat suku bunga Serifikat Bank \\
\hline BJ.Habibie & Krismon & $\begin{array}{l}\text { Indonesia (SBI) } \\
\checkmark \text { Restrukturisasi perbankan melalui Badan } \\
\text { Penyehatan Perbankan Nasional (BPPN) } \\
\checkmark \text { Mengesahkan regulasi pro pasar }\end{array}$ \\
\hline 1999-2001 & & $\checkmark$ Pelebaran investasi asing \\
\hline
\end{tabular}




\begin{tabular}{|c|c|c|}
\hline Abdurrahman & Pemulihan & $\checkmark$ Pembentukan Dewan Ekonomi Nasional \\
\hline Wahid & Krismon & $\begin{array}{l}\checkmark \text { Pembentukan BPR Nusuma sebagai upaya } \\
\text { untuk mengembangkan ekonomi rakyat, } \\
\text { khususnya warga NU }\end{array}$ \\
\hline 2001-2004 & Campuran & $\checkmark$ Penundaan pembayaran utang luar negeri \\
\hline Megawati & & $\checkmark$ Privatisasi BUMN \\
\hline Soekarnoputri & & $\checkmark$ Pendirian Komisi Pemberantasan Korupsi \\
\hline 2004-2014 & Campuran & $\checkmark$ Mengurangi subsidi BBM \\
\hline Soesilo & & $\checkmark$ Bantuan Langsung Tunai (BLT) bagi \\
\hline Bambang & & masyarakat miskin \\
\hline Budiono & & $\checkmark$ Pembangunan infrastruktur massal \\
\hline & & $\checkmark$ Buy back saham BUMN \\
\hline & & $\checkmark$ Anggaran pendidikan 20\% dari APBN \\
\hline & & $\begin{array}{l}\checkmark \text { Memudahkan investor asing untuk berinvestasi } \\
\text { di Indonesia bahkan ke daerah }\end{array}$ \\
\hline \multirow[t]{4}{*}{$\begin{array}{l}\text { 2014-Sekarang } \\
\text { Joko Widodo }\end{array}$} & Campuran & $\begin{array}{l}\checkmark \text { Menerbitkan } 12 \text { paket kebijakan ekonomi yang } \\
\text { bertujuan mempermudah investasi }\end{array}$ \\
\hline & & $\begin{array}{l}\checkmark \text { Pemangkasan birokrasi dalam pemberian ijin } \\
\text { dan pendirian badan usaha }\end{array}$ \\
\hline & & $\checkmark$ Pembangunan infrastruktur konektivitas \\
\hline & & $\checkmark$ Pendirian BPJS \\
\hline
\end{tabular}

Sumber: dihimpun dari berbagai sumber

Sekalipun secara resmi ekonomi kerakyatan belum pernah diterapkan secara nasional, namun pergulatan pemikiran dan perdebatan konsep terjadi bersisisisian dengan konsep ekonomi yang diterapkan. Sempat gagasan ekonomi kerakyatan ini terpuruk lama, maka pada 1967, Emil Salim ${ }^{29}$ mengemukakan ide tentang Ekonomi Pancasila, yang secara garis besarnya adalah sistem perekonomian yang didasarkan pada lima sila dalam Pancasila. Walaupun dalam artikel itu konsep Ekonomi Pancasila yang dimaksud belum begitu jelas, namun pada 1979, Emil Salim ${ }^{30}$ membahas kembali apa yang dimaksudkannya sebagai Ekonomi Pancasila. Pada esensinya, Ekonomi Pancasila adalah suatu konsep kebijaksanaan ekonomi, setelah mengalami pergerakan seperti bandul jam dari kiri ke kanan, hingga mencapai titik keseimbangan. Ke kanan artinya bebas mengikuti aturan pasar, sedangkan ke kiri artinya mengalami intervensi negara dalam bentuk

29 Emil Salim, Sistem Ekonomi dan Ekonomi Indonesia, Jakarta: Lembaga Ekonomi dan Kemasyarakatan Indonesia, 1965, hal. 5. Lihat pula Emil Salim, Politik dan Ekonomi Pancasila, dalam Widjojo Nitisastro dkk., Masalabmasalah Ekonomi dan Faktor-Faktor Ideologi, Poloitik dan Sosial (IPOLOS), LEKNAS, Jakarta, 1965, hlm. 81-97.

${ }^{30}$ Dawam Rahardjo, Ekonomi Pancasila Dalam Tinjauan Filsafat Ilmu, Op. Cit., hlm. 6. 
perencanaan terpusat. Secara sederhana, Ekonomi Pancasila dapat disebut sebagai sebuah sistem ekonomi pasar dengan pengendalian pemerintah atau "ekonomi pasar terkendali". ${ }^{31}$ Dilihat secara konsep, gagasan Ekonomi Pancasila adalah sama dengan Ekonomi Kerakyatan.

Pada tahun 1984, Mubyarto ${ }^{32}$ mengembangkan lebih lanjut konsep Ekonomi Pancasila yang merupakan pemikiran Soekarno, Hatta, dan Emil Salim, pada saat pengukuhan guru besarnya di UGM. Pidato pengukuhannya dengan judul 'Gagasan dan Metoda Berfikir Tokoh-Tokoh Besar Ekonomi dan Penerapannya Bagi Kemajuan Kemanusiaan' menawarkan kembali Sistem Ekonomi Pancasila sebagai terjemahan Demokrasi Ekonomi dan Ekonomi Kerakyatan dalam Pasal 33 UUD 1945. Menurut Mubyarto, Sistem Perekonomian Pancasila memiliki 5 ciri pokok sebagai berikut:

1. Roda kegiatan ekonomi digerakan oleh rangsangan ekonomi, sosial dan moral.

2. Ada kehendak kuat dari warga masyarakat untuk mewujudkan kemerataan sosial, yaitu tidak membiarkan terjadinya ketimpangan ekonomi dan sosial.

3. Dijiwai semangat nasionalisme ekonomi dan tantangannya di era globalisasi yaitu terwujudnya perekonomian nasional yang kuat, tangguh dan mandiri.

4. Demokrasi ekonomi berdasarkan kerakyatan dan kekeluargaan. Dalam konteks ini, koperasi dan usaha kooperatif menjiwai perilaku ekonomi perorangan dan masyarakat.

5. Adanya keseimbangan yang harmonis, efisien dan adil antara perencanaan nasional dengan otonomi yang luas, bebas dan bertanggung jawab menuju terciptanya keadilan sosial.33

Sebelum Mubyarto, di awal Orde Baru Sarbini Sumawinata ${ }^{34}$ mencoba mengangkat kembali gagasan tentang ekonomi kerakyatan. Namun gagasan tersebut dikalahkan oleh gagasan ekonomi neoliberal yang dimotori oleh Widjojo Nitisastro. Bersamaan dengan peristiwa Malari, maka penerapan ekonomi neoliberal pun semakin kukuh di Indonesia. Ketika reformasi bergulir, pemikiran tentang

31 Ibid.

32 Mubyarto, Sistem dan Moral Ekonomi Indonesia, Jakarta: LP3ES, 1988, hlm. 11-13.

${ }^{33}$ Lihat selengkapnya di http://www.kompasiana.com/rizkyfebriana/mengenal-lebih-dekat-profesormubyarto 54f96e94a333111a648b45bc, diakses 30 September 2014

${ }^{34}$ Sarbini Sumawinata, Politik Ekonomi Kerakyatan,Jakarta: PT Gramedia Pustaka Utama, 2004, hlm. 7

Lihat pula tulisan Sarbini Sumawinata dalam Sularto (ed), Masyarakat Warga dan Pergulatan Demokrasi, Menyambut 70 Tahun Jakob Oetomo, PT Komas Media Nusantaral, Jakarta, 2001, hlm. 55 
Ekonomi Kerakyatan atau Ekonomi Pancasila mendapat tempat kembali. Melalui Ketetapan MPR No. VI/MPR/1999 mengenai Ekonomi Kerakyatan, disebutkan bahwa misi ekonomi kerakyatan adalah 'memberdayakan semua kekuatan ekonomi nasional terutama pengusaha kecil, menengah, dan koperasi dengan mengembangkan sistem ekonomi pasar yang adil, berbasis pada sumber daya alam (SDA) dan sumber daya manusia (SDM) yang produktif, mandiri, maju, berdayasaing, berwawasan lingkungan, dan berkelanjutan'. Sedangkan arah kebijakan ekonomi kerakyatan tersebut adalah: 1) bertumpu pada mekanisme pasar yang berkeadilan; 2) berprinsip persaingan yang sehat; 3) memperhatikan pertumbuhan ekonomi; 4) memiliki nilai-nilai keadilan, kepentingan sosial, kualitas hidup, pembangunan berwawasan lingkungan dan berkelanjutan sehingga terjamin kesempatan yang sama baik dalam berusaha/bekerja, perlindungan hak-hak konsumen, serta perlakuan adil bagi seluruh masyarakat. ${ }^{35}$ Selanjutnya agar sistem ekonomi kerakyatan berjalan dengan baik, selain arah kebijakan sebagaimana disebut di atas, diperlukan pula komponen pendukung yang menjadi dasar pelaksanaan ekonomi kerakyatan, yaitu: 1) setiap anggota masyarakat harus berpartisipasi dalam proses produksi nasional. Hal ini sejalan dengan amanat Pasal 27 ayat (2) UUD 1945, "Setiap warga negara berhak mendapat pekerjaan dan penghidupan yang layak bagi kemanusiaan." 2) setiap anggota masyarakat, termasuk fakir miskin dan anak-anak terlantar, harus berpartisipasi dalam menikmati hasil produksi nasional. Hal itu sejalan dengan amanat pasal 34 UUD 1945, "Fakir miskin dan anak-anak yang terlantar dipelihara oleh negara." 3) setiap anggota masyarakat harus berpartisipasi dalam mengendalikan jalannya roda perekonomian nasional. ${ }^{36}$

\footnotetext{
35 Jimly Asshiddiqie, Konstitusi Ekonomi, Loc. Cit., hlm. 357

36 Ibid. Bandingkan pendapat Subiakto Tjakrawerdaya dalam Subiakto Tjakrawerdaya, Revitalisasi Sistem Ekonomi Pancasila, Makalah, disampaikan dalam diskusi di Yayasan Damandiri, Jakarta 25 Januari 2012 hlm. 8-11. Dalam penjelsannya terdapat 8 (delapan) prinsip ekonomi kerakyatan yaitu, 1) sistem Ekonomi Pancasila bertujuan sebesar-besarnya untuk kemakmuran rakyat; 2) keikutsertaan rakyat banyak dalam kepemilikan, proses produksi dan menikmati hasilnya; 3) menggunakan mekanisme pasar yang berkeadilan. Dalam mekanisme ini ditentukan di mana peran negara dan dimana peran pasar; 4) perencanaan strategis ekonomi nasional, artinya negara secar sadar menyusun perekonomian secara nasional untuk menghasilkan blue print ekonomi yang akan menjadi petunjuk arah dan pola kebijakan bagi penyelenggaraan serta alat ukur sekaligus jaminan bagi keikutsertaan seluruh rakyat dalam proses produksi bagi tercapainya kesejahteraan rakyat; 5) koperasi berperan utama di sektor ekonomi rakyat; 6) BUMN berperan utama dalam kegiatan-kegiatan ekonomi yang strategis dan atau menguasai hajat hidup orang banyak; 7) kemitraan yang setara antara Koperasi-BUMN-Swasta; dan 8) perencanaan pemerintah sebagai
} 
Semua gagasan tersebut di atas, pada prinsipnya sebagai upaya membangun paradigm ekonomi kerakyatan agar dapat dilaksanakan, sehingga perlu dan harus diprakarsai serta dimulai oleh negara. Kebijakan ekonomi yang menggunakan prinsip di atas, menjadi langkah awal yang menunjukkan bahwa sistem ekonomi kerakyatan menjadi soko guru ekonomi Indonesia.

\section{Penerapan Prinsip Ekonomi Kerakyatan Dalam Usaha Mikro, Kecil dan Menengah}

Sebagaimana disebutkan dalam Ketetapan MPR No. VI/MPR/1999, salah satu kekuatan ekonomi kerakyatan adalah pengusaha kecil dan menengah, di samping koperasi. Tulisan ini berfokus pada implementasi sistem ekonomi kerakyatan untuk pemberdayaan usaha mikro, kecil, dan menengah semata. Alasan untuk itu adalah pada saat ini lebih banyak sektor usaha mikro, kecil, dan menengah yang ambil peran dalam dunia usaha nasional. Menurut data dari Kementerian Koperasi dan Usaha Kecil dan Menengah, pada 2012, ada sebanyak 56.534.592 usaha mikro, kecil dan menengah yang menempati 99,99\% dari unit usaha yang ada di pasar. Angka ini walaupun meningkat jumlahnya pada 2013 menjadi 57.895.721, namun persentasinya tetap 99,99\%. Namun demikian, terlihat bahwa sebagian besar pelaku usaha adalah pengusaha mikro, kecil dan menengah. Pengertian dan pembatasan usaha mikro, kecil dan menengah diatur dalam Undang-Undang Nomor 20 Tahun 2008 Tentang Usaha Mikro, Kecil, Dan Menengah memberi batasan tentang usaha mikro, usaha kecil, dan usaha menengah sebagai berikut:

1. Usaha Mikro adalah usaha produktif milik orang perorangan dan/atau badan usaha perorangan yang memenuhi kriteria:

a. memiliki kekayaan bersih paling banyak Rp. 50.000.000,00 tidak termasuk tanah dan bangunan tempat usaha; atau

b. memiliki hasil penjualan tahunan paling banyak Rp. 300.000.000,00.

2. Usaha Kecil adalah usaha ekonomi produktif yang berdirisendiri, yang dilakukan oleh orang perorangan atau badanusaha yang bukan merupakan anak perusahaan atau bukancabang perusahaan yang dimiliki, dikuasai, atau

penafsiran pendistribusian sumber daya alam dan seluruh kekayaan negara dilaksanakan oleh Pemerintah untuk menjamin kesejahteraan bersama. 
menjadi bagian baik langsung maupun tidak langsung dari Usaha Menengah atau Usaha Besar yang memenuhi kriteria:

a. memiliki kekayaan bersih lebih dari Rp. 50.000.000,00 sampai dengan paling banyak Rp 500.000.000,00 tidak termasuk tanah dan bangunan tempat usaha; atau

b. memiliki hasil penjualan tahunan lebih dari Rp. 300.000.000,00 sampai dengan paling banyak Rp. 2.500.000.000,00.

3. Usaha Menengah adalah usaha ekonomi produktif yang berdiri sendiri, yang dilakukan oleh orang perorangan atau badan usaha yang bukan merupakan anak perusahaan atau cabang perusahaan yang dimiliki, dikuasai, atau menjadi bagian baik langsung maupun tidak langsung dengan Usaha Kecil atau Usaha Besar dengan kriteria sebagai berikut:

a. memiliki kekayaan bersih lebih dari Rp. 500.000.000,00 sampai dengan paling banyak Rp. 10.000.000.000,00 tidak termasuk tanah dan bangunan tempat usaha; atau

b. memiliki hasil penjualan tahunan lebih dari Rp. 2.500.000.000,00 sampai dengan paling banyak Rp. 50.000.000.000,00.

Berdasarkan kriteria di atas, jelas bahwa yang dijadikan ukuran sebagai kriteria usaha mikro, kecil dan menegah adalah besar modal dan keuntungan perusahaan. Dikaitkan dengan konsep ekonomi kerakyatan di atas, maka pemberdayaan UMKM sangat dimungkinkan menggunakan konsep dimaksud. Seperti yang diutarakan oleh Tjakrawerdaja, salah satu kriteria ekonomi kerakyatan adalah keikutsertaan rakyat banyak dalam kepemilikan, proses produksi dan menikmati hasilnya. Namun demikian, dari 8 (delapan) kriteria yang diusulkannya, penerapan sistem koperasi sebagai pemeran utama menjadi tantangan terbesar. Dalam pemikiran Tjakrawerdana, maka idealnya UMKM diberdayakan melalui sistem koperasi. ${ }^{37}$

${ }^{37}$ Ibid, hlm. 15. Dalam paparannya Subiakto Tjokrowerdaya menguraikan bahwa dalam usaha membangun system ekonomi Pancasila yang bertumpu pada kerakyatan harus dilakukan, Pertama, membuat undang-undang sistem perekonomian nasional dan garis-garis besar arah strategi pembangunan jangka panjang. Kedua,, menyempurnakan UU anti monopoli dan persaingan tidak sehat menjadi UU kemitraan nasional terutama dengan melakukan penajaman tata peran dan tata kelola pelaku ekonomi [BUMN-Koperasi-Swasta] dan menjadikan kemitraan sebagai gerakan nasional. Ketiga, membangun resource-base industry yang berdaya saing tinggi sebagai prioritas utama.Keempat, pemberdayaan Koperasi agar berperan utama dalam ekonomi rakyat. Kelima, memperkuat BUMN yang menguasai hajat hidup orang banyak dan strategis agar berdaya saing tinggi dan menjadilokomotif ekonomi rakyat. Keenam, melakukan gerakan cinta produksi dalam negeri. Ketujuh, melaksanakan gerakan produktifitas dan efesiensi nasional. Kedelapan, menyegerakan reformasi birokrasi guna mewujudkan pemerintahan bersih dan berwibawa. 
Tabel 3

Sebaran koperasi menurut skala usaha

\begin{tabular}{|l|r|r|r|r|r|r|r|r|r|}
\hline $\begin{array}{l}\text { Skala } \\
\text { Usaha }\end{array}$ & $\mathbf{1 9 9 7}$ & $\mathbf{1 9 9 8}$ & $\mathbf{1 9 9 9}$ & $\mathbf{2 0 0 0}$ & $\mathbf{2 0 0 1}$ & $\mathbf{2 0 0 3}$ & $\mathbf{2 0 0 4}$ & $\mathbf{2 0 0 5}$ & $\mathbf{2 0 0 6}$ \\
\hline UK & 39.704 & 36.761 & 37.804 & 39.705 & 39.883 & 43.372 & 44.684 & 47.006 & 48.822 \\
UM & 60 & 51 & 51 & $\mathbf{7 8}$ & 81 & 87 & 93 & 96 & 106 \\
UB & 2 & 1 & 1 & 5 & 5 & 6 & 6 & 6 & 7 \\
\hline Total & 39.766 & 36.813 & 37.856 & 39.788 & 39.969 & 43.465 & 44.783 & 47.108 & 49.035 \\
\hline
\end{tabular}

Sumber: BPS

Dari data di atas terlihat bahwa sebagian besar koperasi diterapkan untuk usaha kecil; sehingga upaya untuk mendorong UMKM dengan menggunakan koperasi sebetulnya sudah dimulai. Namun demikian, perlu juga dipertimbangkan kemampuan kinerja koperasi dalam melayani UMKM dimaksud. Jika dilihat perbandingan UMKM dengan koperasi yang tersedia dari sejumlah 56.534 .592 UMKM, hanya ada 147.249 koperasi; sehingga kurang lebih secara rata-rata 1 koperasi melayani 384 UMKM sehingga efektifitas pelayanan bisa menjadi masalah tersendiri. Secara umum masalah kinerja koperasi di Indonesia diakui oleh banyak pihak sehingga koperasi dianggap belum bisa bersaing di tingkat nasional dengan sistem ekonomi pasar yang diterapkan sekarang ini. Padahal, secara normatif, Kementerian Koperasi dan UMKM telah mencoba menyusun penilaian kinerja koperasi secara kuantitatif sebagaimana diatur dalam Kepmen No. 129/Kep/M.KUKM/XI/2002, yang rinciannya sebagai berikut:

Tabel 4

Kriteria Kinerja Koperasi Menurut Kepmen No. 129/Kep/M.KUKM/XI/2002

\begin{tabular}{|llc|}
\hline No & \multicolumn{1}{c|}{ Prinsip dan Faktor } & Bobot \\
\hline 1 & Keanggotaan sukarela dan terbuka & 8 \\
& $\begin{array}{l}\text { a. Rasio peningkatan jumlah anggota (4) } \\
\text { b. Rasio pencatatan keanggotaan dalam buku daftar anggota (4) }\end{array}$ & \\
2 & $\begin{array}{l}\text { Pengendalian oleh anggota secara demokratis } \\
\text { a. Penyelenggaraan RAT (4) }\end{array}$ & \\
& $\begin{array}{l}\text { b. Rasio kehadiran anggota dalam RAT (4) } \\
\text { c. Rencana kegiatan (RK) dalam rencana anggaran pendapatan dan } \\
\end{array}$ & \\
& belanja koperasi (2)
\end{tabular}




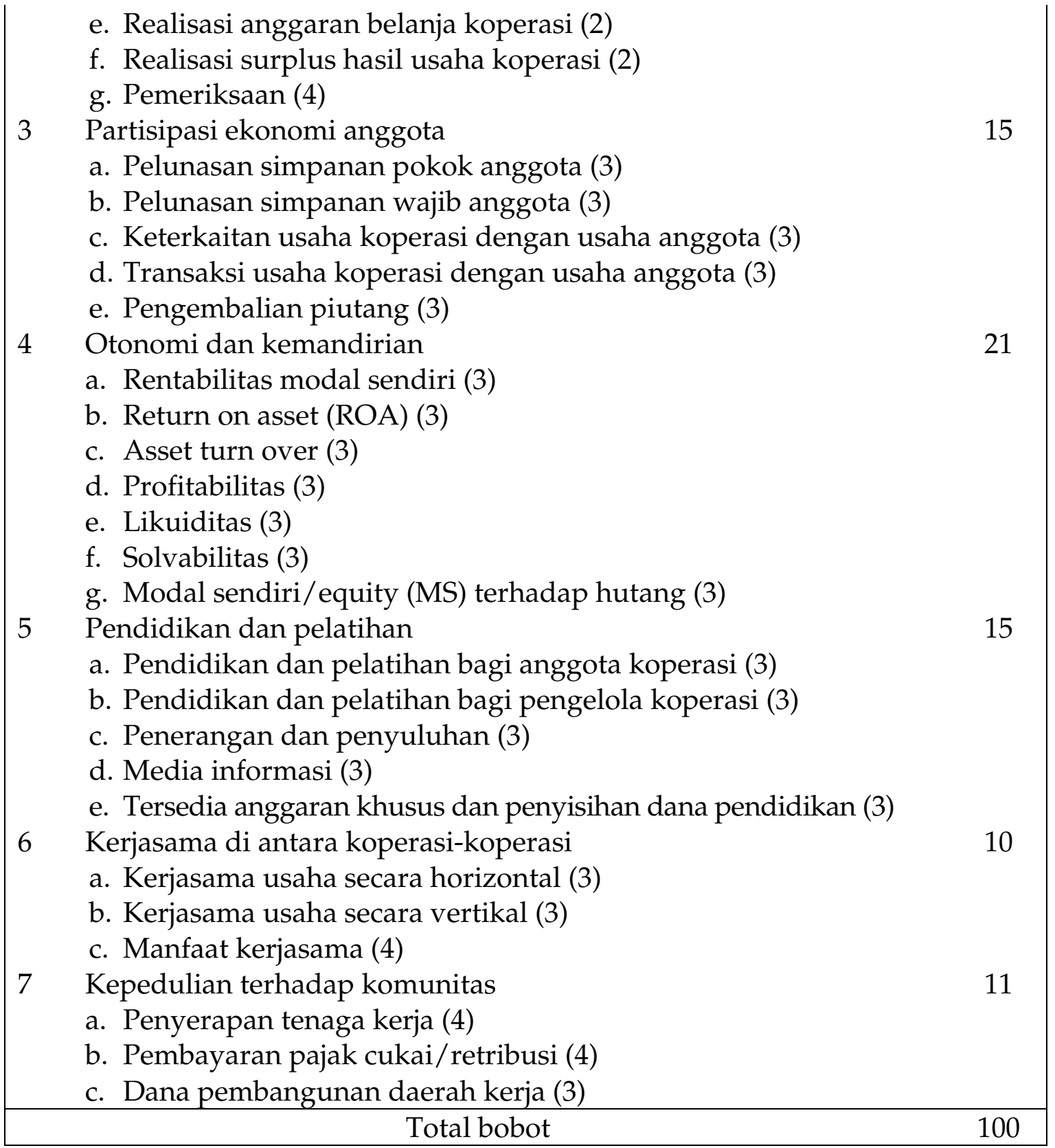

Beberapa penelitian menunjukkan bahwa dari 7 faktor kemandirian koperasi di atas, kelemahan utama terletak pada faktor keempat (otonomi dan kemandirian), dan faktor kelima (pendidikan dan latihan). Lemahnya faktor otonomi dan kemandirian dapat dilihat dari masih sangat jarangnya koperasi yang diaudit secara independen dan melakukan perencanaan secara terstruktur. Sedangkan analisis rasio keuangan/tingkat kesehatan hanya bersifat apa adanya dari sistem yang digunakan. Padahal faktor ini merupakan faktor utama dalam menjalankan bisnis/usaha. Untuk faktor pendidikan dan pelatihan dianggap belum memadai karena orientasi 
pendidikan pada koperasi lebih dititikberatkan kepada karyawan, masih sangat jarang koperasi yang melakukan pendidikan kepada anggotanya. Sedangkan prinsip utama koperasi adalah keaktifan anggotanya ${ }^{38}$.

\section{Penutup}

Berdasarkan uraian di atas, sesungguhnya peran negara sangat besar untuk menerapkan sistem ekonomi kerakyatan sebagaimana yang dikehendaki oleh Pasal 33 UUD 1945. Oleh karena itu, pembahasan secara komprehensif mengenai reformasi terhadap sistem ekonomi kerakyatan telah dilakukan dalam kerangka reformasi sistem perekonomian yang menyentuh seluruh sub-sistem yang dibutuhkan dalam penyelenggaraan perekonomian yang berbasis rakyat.

Dalam kerangka melaksanakan amanat Pasal 33 UUD 1945 tersebut, konstitusi juga telah menetapkan salah satu alat yang dapat digunakan oleh negara untuk dapat mengimplementasikan semnagat kekeluargaan yang terkandung dalam pasal tersebut, yaitu Pasal 1 ayat (2) dan ayat (3) UUD 1945. Formulasi normatif yang ditetapkan dalam pasal tersebut memberikan makna bahwa hukum sebagai sarana pelaksanannya, sehingga memberikan posisi yang kuat kepada negara dalam hal ini pemerintah untuk aktif dalam menetapkan rumusan hukum yang berisi pelaksanaan sistem eknomi kerakyatan yang diamanatkan oleh Pasal 33 UUD 1945.

Praktik pelaksanaan koperasi sebagai bagian bentuk system ekonomi kerakyatan masih kurang memuaskan, namun kekurangpuasan itu lebih dipicu karena kurangnya peningkatan kapasitas baik anggota maupun pengelola koperasi. Koperasi seringkali diasumsikan dan dianggap sebagai bentuk badan usaha lain seperti PT atau CV yang anggotanya tidak dituntut bertindak aktif. Sementara kunci utama dari keberhasilan koperasi terletak pada aktif tidaknya anggota. Hasil evaluasi yang dilakukan oleh Kementerian Koperasi dan UMKM menunjukkan bahwa kebanyakan koperasi yang tidak aktif itu karena salah urus

\footnotetext{
${ }^{38}$ Lihat Ichwan Marisan dan Purwo Adi Wibowo, Penelitian Survei Penerapan Prinsip-Prinsip Koperasi Pada Koperasi Simpan Pinjam Di Kab. Jepara, The 3rd University Research Colloquium, 2016, hlm. 279.
} 
disebabkan anggotanya tidak aktif secara berkelanjutan; aktifnya anggota hanya pada saat pendirian saja.

Usaha mikro, kecil dan menengah secara proporsi, menempati jumlah terbesar untuk skala usaha di Indonesia. Berdasarkan 8 kriteria ekonomi kerakyatan yang dikemukakan di atas, maka usaha mikro, kecil dan menengah sangat strategis jika diberdayakan dengan menggunakan pendekatan ekonomi kerakyatan. Dalam perspektif ini, maka negara harus berperan aktif untuk mengatasi hambatan-hambatan pelaksanaan ekonomi kerakyatan dalam praktiknya. Dengan menggunakan prinsip pembinaan dalam manajemen secara umum, maka Kementerian Koperasi dan UMKM perlu melakukan upaya pembinaan secara berkesinambungan dalam bentuk antara lain sosialisasi, penelitian, koordinasi, maupun bimbingan serta pendampingan untuk bisa mendorong 56.534.592 UMKM lebih efektif dan pada akhirnya dapat berkontribusi kepada pembangunan di Indonesia.

\section{Daftar Pustaka}

\section{Buku}

Asshiddiqie, Jimly, Konstitusi Ekonomi, PT Kompas Media Nusantara, Jakarta, 2010. , Komentar Atas Undang-Undang Dasar Negara Republik Indonesia Tahun 1945, Sinar Grafika, Jakarta, 2009.

Baswir, Revrisond, Tiada Ekonomi Kerakyatan Tanpa Kedaulatan Rakyat, dalam Baswir (1997), Agenda Ekonomi Kerakyatan, Pustaka Pelajar, Yogyakarta (2000),

Djajadiningrat, Surna Tjahja, Yeni Hendriani, Melia Famiola, Green Economy/Ekonomi Hijau, cetakan pertama, Rekayasa Sains Bandung, Bandung, 2014.

Hendar dan Kusnadi, Ekonomi Koperasi, edisi kedua Lembaga Penerbit FE-UI, Jakarta, 2005.

Limbong, Bernhard, Ekonomi Kerakyatan dan Nasionalisme Ekonomi, Margaretha Pustaka, Jakarta, 2013.

Lubis, Efridani, Perlindungan dan Pemanfaatan Sumber Daya Genetik Berdasarkan Penerapan Konsep Sovereign Right dan Hak Kekayaan Intelektual, Penerbit Alumni, Bandung, 2009.

Madjid, Abdul dan Sri Edi Swasono (eds.), Wawasan Ekonomi Pancasila, UI Press, Jakarta, 1981. 
Maftuchan, Ah, Mickael B. Hoelman, Victoria Fanggidaer (ed), Transformasi Kesejahteraan: Pemenuhan Hak Ekonomi dan Kesehatan Semesta, cetakan pertama, Penerbit LP3ES, Jakarta, 2016.

Mubyarto, Beberapa Ciri dan Landasan Pikiran Sistem Ekonomi Pancasila, dalam Sistem Ekonomi dan Demokrasi Ekonomi, Sri Edi Swasoono (Ed), UI Press, Jakarta.

Partadiredja, Ace, Pengantar Ekonomika, BPFE UII, Yogyakarta, 1984.

Ramli, Rizal, Telaah Wacana Ekonomi Kerakyatan dalam Ekonomi Kerakyatan, Lembaga Suluh Nusantara Bekerjasama dengan American Institute For Indonesian Studies (AIFIS), 2014.

Setiawan, Bonnie, Peralihan Kapitalisme di Dunia Ketiga: Teori Radikal dari Klasik Sampai Kontemporer, Insist Press, Yogyakarta, 1999.

Soesastro, Hadi dalam Ross Mc Leod \& Ross Garnaut, East Asia in Crisis: From being a Miracle to Needing me?, 1998.

Sularto (ed), Masyarakat Warga dan Pergulatan Demokrasi, Menyambut 70 Tahun Jakob Oetomo, PT Komas Media Nusantaral, Jakarta, 2001.

Sumawinata, Sarbini, Politik Ekonomi Kerakyatan. PT Gramedia Pustaka Utama, Jakarta, 2004.

\section{Hasil Penelitian/Makalah}

Mahfud, Moh., MD, Perkembangan Politik Hukum, Studi tentang Pengaruh Konfigurasi Politik terhadap Produk Hukum di Indonesia, Disertasi Doktor dalam Ilmu Hukum di Univeristas Gajah Mada, Yogyakarta, 1993.

Hutomo, Mardi Yatmo, Konsep Ekonomi Kerakyatan, Makalah disampaikan dalam diskusi di Kementerian Perencanaan Pembangunan Nasional/Badan Perencanaan Pembangunan Nasional (BAPPENAS), 14 Oktober 2009.

Idris, Amiruddin, Penguatan Ekonomi Kerakyatan Berdasarkan Demokrasi Ekonomi Makalah di sampaikan dalam Diskusi Ilmiah MPR RI dan Universitas Almuslim, 2012.

Tjakrawerdaja, Subiakto, Revitalisasi Sistem Ekonomi Pancasila, Makalah disampaikan dalam diskusi di Yayasan Damandiri, Jakarta 25 Januari 2012. Salim, Emil, 'Sistem Ekonomi Pancasila', Prisma, No. 5, Mei 1979.

\section{Putusan Pengadilan}

Putusan Mahkamah Konstitusi Perkara Nomor 001-021-022/PUU-I/2003 tentang Pengujian UU No. 20 Tahun 2002 tentang Ketenagalistrikan.

Putusan Perkara Nomor 002/PUU-I/2003 mengenai Pengujian UU No. 22 Tahun 2001 Tentang Minyak dan Gas Bumi. 
Putusan Perkara No. 058-059-060-063/PUU-II/ 2004 mengenai Pengujian UU No. 7 Tahun 2004 tentang Sumber daya Air.

Putusan No. 21-22/PUU-V/2007 mengenai Pengujian UU No.25 Tahun 2007 tentang Penanaman Modal.

\section{Internet}

Mengenang Prof Mubyarto - Sewindu Kepulangan Sang Guru, http://www.kompasiana.com/laurenciussimanjuntak/mengenang-profmubyarto-sewindu-kepulangan-sang-guru_552e1ba76ea834a23d8b4580.

Tarigan, Syawal Efendi, Ekonomi Kerakyatan Antara Konsep dan Realita, http://www.kompasiana.com/syawal_efendi_tarigan/ekonomikerakyatan-antara-konsep-dan-realita_552e22f36ea834f8088b456a.

"Prof Mubyarto dan Ekonomi Pancasila" http://poskotanews.com, diakses tanggal 27 April 2014.

Rahardjo, Dawam. Ekonomi Pancasila Dalam Tinjauan Filsafat Ilmu. http://www.ekonomikerakyatan.ugm.ac.id, diakses tanggal 27 April 2014. 